\title{
IDENTIFIKASI JENIS KERUSAKAN JALAN (Studi Kasus Ruas Jalan Kedungmundu-Meteseh)
}

\author{
Farida Yudaningrum ${ }^{1}$, Ikhwanudin ${ }^{2}$ \\ ${ }^{1}$ Fakultas Teknik, Jurusan Teknik Sipil, Universitas PGRI Semarang \\ farida17061978@gmail.com \\ ${ }^{2}$ Fakultas Teknik, Jurusan Teknik Sipil, Universitas PGRI Semarang \\ ikhwan menur@yahoo.com
}

\begin{abstract}
ABSTRAK: Jalan merupakan salah satu jenis prasarana transportasi darat yang memegang peranan penting bagi pengembangan suatu daerah. Ruas jalan Kedungmundu-Meteseh merupakan jalan Kolektor yang mempunyai frekwensi lalu lintas tinggi sebagai penghubung Semarang Selatan dengan Semarang Timur. Kerusakan-kerusakan yang terjadi tentu akan berpengaruh pada keamanan dan kenyamanan pemakai jalan.

Kerusakan jalan dapat disebabkan oleh beberapa faktor, diantaranya air, perubahan suhu, cuaca, temperatur udara, material konstruksi perkerasan, kondisi tanah dasar yang tidak stabil, proses pemadatan di atas lapisan tanah dasar yang kurang baik dan tonase atau muatan kendaraankendaraan berat yang melebihi kapasitas serta volume kendaraan yang semakin meningkat.

Jenis kerusakan yang mendominasi pada ruas jalan tersebut berupa bleeding sebesar $482 \mathrm{~m}^{2}$ atau $39,18 \%$ serta retak rambut dan retak kulit buaya sebesar $456 \mathrm{~m}^{2}$ atau $37,07 \%$ dari total kerusakan yang terjadi sepanjang ruas jalan tersebut. Bleeding dapat disebabkan pemakaian kadar aspal yang tinggi pada campuran aspal, pemakaian terlalu banyak aspal pada pekerjaan prime coat atau tack coat sehingga permukaan menjadi licin. Pada temperatur tinggi, aspal menjadi lunak dan akan terjadi jejak roda.

Sedangkan kerusakan retak rambut dapat meresapkan air kedalam lapis permukaan. Retak rambut dapat berkembang menjadi retak kulit buaya. Retak kulit buaya dapat diresapi pula oleh air sehingga jika tidak segera ditangani dapat mengakibatkan terjadinya lubang-lubang kecil akibat terlepasnya butir-butir. Hal ini akan mengakibatkan sangat tidak nyamannya pengendara menggunakan jalan tersebut.
\end{abstract}

Kata Kunci: kerusakan retak jalan

ABSTRACT: The road is one type of land transportation infrastructure plays an important role for the development of a region. Road section Kedungmundu - Meteseh a collector roads that have high traffic frequency as South Semarang liaison with the East Semarang. The damages that occur naturally will affect the safety and comfort of road users.

Road damage can be caused by several factors, including water, changes in temperature, weather, air temperature, material pavement construction, soil conditions unstable base, the process of compaction in the top layer of subgrade poorly and tonnage or cargo vehicles - heavy vehicles exceeding capacity as well as increasing the volume of vehicles.

This type of damage that dominate the roads in the form of bleeding amounted to $482 \mathrm{~m}^{2}$, or $39.18 \%$ as well as hair cracking and alligator cracking of $456 \mathrm{~m} 2$ or $37.07 \%$ of the total damage that occurred during the Road Sections. Bleeding can be caused by the use of high binder content in asphalt mixtures, the use of too many prime coat of asphalt on the job or tack coat so that the surface becomes slippery. At high temperatures, the asphalt becomes soft and will happen ruts.

While damage to hair cracks can absorb water into the surface layer. Hairline cracks can develop into alligator cracks. Alligator cracking can be impregnated well by water so that if not addressed promptly can result in holes - small holes caused by the release beads. This will result in very uncomfortable motorists using the road.

Keywords: damage, road, cracks

\section{PENDAHULUAN}

Jalan merupakan salah satu jenis prasarana transportasi darat yang memegang peranan penting bagi pengembangan suatu daerah. Kondisi jalan yang baik akan memudahkan mobilitas penduduk dalam mengadakan kegiatan ekonomi dan kegiatan sosial lainnya. Ruas jalan Kedungmundu-Meteseh merupakan jalan Kolektor yang mempunyai frekwensi lalu lintas tinggi sebagai penghubung Semarang Selatan dengan Semarang 
Timur. Kerusakan-kerusakan yang terjadi tentu akan berpengaruh pada keamanan dan kenyamanan pemakai jalan.

Kerusakan jalan dapat disebabkan oleh beberapa faktor, diantaranya air, perubahan suhu, cuaca, temperatur udara, material konstruksi perkerasan, kondisi tanah dasar yang tidak stabil, proses pemadatan di atas lapisan tanah dasar yang kurang baik dan tonase atau muatan kendaraan-kendaraan berat yang melebihi kapasitas serta volume kendaraan yang semakin meningkat.

Kenyataan di lapangan menunjukan bahwa pada jaringan jalan tertentu khususnya di perkotaan terjadi ketidakseimbangan antara tingkat pertumbuhan jalan disatu sisi dengan tingkat pertumbuhan kendaraan disisi yang lain, dimana pertumbuhan jalan jauh lebih kecil daripada tingkat pertumbuhan kendaraan, hal ini berarti menunjukkan terjadinya pembebanan yang belebihan pada jalan.

Oleh sebab itu penanganan konstruksi perkerasan baik yang bersifat pemeliharaan, peningkatan atau rehabilitasi akan dapat dilakukan secara optimal apabila faktor-faktor penyebab kerusakan pada kedua ruas jalan tersebut telah diketahui.

Dalam mengevaluasi kerusakan jalan perlu ditentukan jenis kerusakan (distress type) dan penyebabnya, tingkat kerusakan (distress severity) dan jumlah kerusakan (distress amount).

\section{TINJAUAN PUSTAKA}

\subsection{Jalan}

Menurut Peraturan Pemerintah Nomor 34 Tahun 2006, jalan adalah prasarana transportasi darat yang meliputi segala bagian jalan, termasuk bangunan pelengkap dan perlengkapannya yang diperuntukkan bagi lalu lintas, yang berada pada permukaan tanah, di atas permukaan tanah, di bawah permukaan tanah dan/atau air, serta di atas permukaan air, kecuali jalan kereta api, jalan lori, dan jalan kabel.

\subsection{Survei Kondisi Jalan}

Menurut Shahin (1994) dalam Hardiyatmo (2007), menyatakan bahwa survei kondisi adalah survei yang dimaksudkan untuk menentukan kondisi perkerasan pada waktu tertentu. Tipe survei semacam ini tidak mengevaluasi kekuatan perkerasan. Survei kondisi bertujuan untuk menunjukan kondisi perkerasan pada saat waktu dilakukan survei. Jadi, survei ini sifatnya kualitatif. Informasi yang diperoleh akan digunakan untuk menetapkan: macam studi, penilaian prioritas dan program pemeliharaan. Survei kondisi juga berguna untuk persiapan analisis struktural secara detail, dan untuk rehabilitasi. Jika area-area secara baik direferensikan dalam stasiun-stasiun, maka area yang membutuhkan pengumpulan data yang lebih intensif dapat didefinisikan.

\subsection{Survei Kerusakan Perkerasan}

Survei kerusakan secara detail dibutuhkan sebagai bagian dari perencanaan dan perancang proyek rehabilitasi. Survei kerusakan perkerasan adalah kompilasi dari berbagai tipe kerusakan, tingkat keparahan kerusakan, lokasi, dan luas penyebarannya. Perhatian harus diberikan terhadap konsistensi dari personil penilai kerusakan baik secara individual maupun kelompok-kelompok yang melakukan survei. Tujuan dilakukannya survei kinerja perkerasan, adalah untuk menentukan perkembangan dari kerusakan perkerasan, sehingga dapat dilakukan estimasi biaya pemeliharaan. Informasi ini sangat berguna untuk instansi yang terkait dalam pengalokasian dana untuk pemeliharaan. Pekerjaan ini sangat penting dan umumnya diprioritaskan sehingga banyaknya biaya yang dibutuhkan untuk pemeliharaan dapat diestimasikan dari tahun ke tahun. Selain itu, survei kinerja perkerasan juga berguna untuk menentukan sebab-sebab dan pengaruh dari kerusakan perkerasan. Penentuan sebab-sebab kerusakan harus diketahui sebelum penanganan pemeliharaan yang memadai dapat dilakukan. Demikian pula penyebab kegagalan perkerasan harus juga diketahui, sehingga hal ini dapat diperhitungkan dalam perancangan di kemudian hari. 
Secara garis besar kerusakan dapat dibedakan menjadi dua bagian, yaitu kerusakan struktural, mencakup kegagalan perkerasan atau kerusakan dari satu atau lebih komponen perkerasan yang mengakibatkan perkerasan tidak dapat lagi menanggung beban lalu lintas; dan kerusakan fungsional yang mengakibatkan keamanan dan kenyamanan pengguna jalan menjadi terganggu sehingga biaya operasi kendaraan semakin meningkat. (Sulaksono, 2001).

Menurut manual pemeliharaan jalan No : 03/MN/B/1983 yang dikeluarkan oleh Direktorat Jenderal Bina Marga, kerusakana jalan dapat dibedakan atas:

1. Retak (cracking)

2. Distorsi (distortion)

3. Cacat permukaan (disintegration)

4. Pengausan (polished aggregate)

5. Kegemukan (bleeding of flushing)

6. Penurunan pada bekas penanaman utilitas

a. Retak (tracking) dan penyebabnya

Retak yang terjadi pada lapisan permukaan jalan dapat dibedakan atas :

1. Retak halus (hair cracking), lebar celah lebih kecil atau sama dengan $3 \mathrm{~mm}$, penyebab adalah bahan perkerasan yang kurang baik, tanah dasar atau bagian perkerasan di bawah lapis permukaan kurang stabil. Retak halus ini dapat meresapkan air kedalam lapis permukaan. Untuk pemeliharaan dapat dipergunakan lapis latasir atau buras. Dalam tahap perbaikan sebaiknya dilengkapi dengan perbaikan sistem drainase. Retak rambut dapat berkembang menjadi retak kulit buaya.

2. Retak kulit buaya (alligator crack), lebar celah lebih besar atau sama dengan $3 \mathrm{~mm}$. Saling merangkai membentuk serangkaian kotak-kotak kecil yang menyerupai kulit buaya. Retak ini disebabkan oleh bahan perkerasan yang kurang baik, pelapukan permukaan, tanah dasar atau bagian perkerasan di bawah lapis permukaan kurang stabil, atau bahan lapis pondasi dalam keadaan jenuh air (air tanah naik).

Umumnya daerah dimana terjadi retak kulit buaya tidak luas. Jika daerah dimana terjadi retak kulit buaya luas, mungkin hal ini disebabkan oleh repetisi beban lalulintas yang melampaui beban yang dapat dipikul oleh lapisan permukaan tersebut. Retak kulit buaya untuk sementara dapat dipeliharan dengan mempergunakan lapis burda, burtu, ataupun lataston, jika celah $\leq 3 \mathrm{~mm}$. Sebaiknya bagian perkerasan yang telah mengalami retak kulit buaya akibat air yang merembes masuk ke lapis pondasi dan tanah dasar diperbaiki dengan cara dibongkar dan membuang bagian-bagian yang basah, kemudian dilapis kembali dengan bahan yang sesuai. Perbaikan harus disertai dengan perbaikan drainase di sekitarnya. Kerusakan yang disebabkan oleh beban lalulintas harus diperbaiki dengan memberi lapis tambahan. Retak kulit buaya dapat diresapi oleh air sehingga lama kelamaan akan menimbulkan lubang-lubang akibat terlepasnya butir-butir.

3. Retak pinggir (edge crack), retak memanjang jalan, dengan atau tanpa cabang yang mengarah ke bahu dan terletak dekat bahu. Retak ini disebabkan oleh tidak baiknya sokongan dari arah samping, drainase kurang baik, terjadi penyusutan tanah, atau terjadinya settlement di bawah daerah tersebut. Akar tanaman yang tumbuh di tepi perkerasan dapat pula menjadi sebab terjadinya retak pinggir itu. Di lokasi retak, air dapat meresap yang dapat semakin merusak lapis permukaan. Retak dapat diperbaiki dengan mengisi celah dengan campuran aspal cair dan pasir. Perbaikan drainase harus dilakukan, bahu diperlebar dan dipadatkan. Jika penggir perkerasan mengalami penurunan, elevasi dapat diperbaiki dengan menggunakan hotmix. Retak ini lama kelamaan akan bertambah besar disertai dengan terjadinya lubang-lubang.

4. Retak sambungan bahu dan perkerasan (edge joint crack), retak memanjang, umumnya terjadi pada sambungan bahu dengan perkerasan. Retak dapat disebabkan oleh kondisi drainase di bawah bahu jalan lebih buruk daripada di bawah perkerasan, terjadi settlement di bahu jalan, penyusutan material bahu atau 
perkerasan jalan, atau akibat lintasan truk/kendaraan berat di bahu jalan. Perbaikan dapat dilakukan seperti perbaikan retak refleksi.

5. Retak sambungan jalan (lane joint crack), retak memanjang, yang terjadi pada sambungan 2 lajur lalu-lintas. Hal ini disebabkan tidak baiknya ikatan sambungan kedua lajur. Perbaikan dapat dilakukan dengan memasukan campuran aspal cair dan pasir ke dalam celah-celah yang terjadi. Jika tidak diperbaiki, retak dapat berkembang menjadi lebar karena terlepasnya butir-butir pada tepi retak dan meresapnya air ke dalam lapisan.

6. Retak sambungan pelebaran jalan (widening cracks), adalah retak memanjang yang terjadi pada sambungan antara perkerasan lama dengan perkerasan pelebaran. Hal ini disebabkan oleh perbedaan daya dukung dibawah bagian pelebaran dan bagian jalan lama, dapat juga disebabkan oleh ikatan antara sambungan tidak baik. Perbaikan dilakukan dengan mengisi celah-celah yang timbul dengan campuran aspal cair dan p.asir. Jika tidak diperbaiki, air dapat meresap masuk ke dalam lapisan perkerasan melalui celah-celah, butir-butir dapat lepas dan retak bertambah besar.

7. Retak refleksi (reflection cracks), retak memanjang, melintang, diagonal, atau membentuk kotak. Terjadi pada lapis tambahan (overlay) yang menggambarkan pola retakan di bawahnya. Retak refleksi dapat terjadi jika retak pada perkerasan lama tidak diperbaiki secara baik sebelum pekerjaan overlay dilakukan. Retak refleksi dapat pula terjadi jika terjadi gerakan vertikal/horizontal di bawah lapis tambahan sebagai akibat perubahan kadar air pada jenis tanah yang ekspansip. Untuk retak memanjang, melintang dan diagonal perbaikan dapat dilakukan dengan mengisi celah dengan campuran aspal cair dan pasir. Untuk retak berbentuk kotak, perbaikan dilakukan dengan membongkar dan melapis kembali dengan bahan yang sesuai.

8. Retak susut (shrinkage cracks), retak yang saling bersambungan membentuk kotak kotak besar dengan sudut tajam. Retak disebabkan oleh perubahan volume pada lapisan permukaan yang memakai aspal dengan penetrasi rendah, atau perubahan volume pada lapisan pondasi dan tanah dasar. Perbaikan dapat dilakukan dengan mengisi celah dengan campuran aspal cair dan pasir dan dilapisi dengan burtu.

9. Retak slip (slippage cracks), retak yang bentuknya melengkung seperti bulan sabit, hal ini terjadi disebabkan oleh kurang baiknya ikatan antara lapis permukaan dan lapis di bawahnya. Kurang baiknya ikatan dapat disebabkan oleh adanya debu, minyak, air atau benda non adhesif lainnya, atau akibat tidak diberinya tack coat sebagai bahan pengikat di antara kedua lapisan. Retak selip pun dapat terjadi akibat terlalu banyaknya pasir dalam campuran lapisan permukaan, atau kurang baiknya pemadatan lapis permukaan. Perbaikan dapat dilakukan dengan membongkar bagian yang rusak dan menggantikannya dengan lapisan yang lebih baik.

\section{b. Distorsi (Distortion)}

Distorsi/perubahan bentuk dapat terjadi akibat lemahnya tanah dasar, pemadatan yang kurang pada lapis pondasi, sehingga terjadi tambahan pemadatan akibat beban lalu lintas. Distorsi (Distortion) dapat dibedakan atas:

1. Alur (Ruts), yang terjadi pada lintasan roda sejajar dengan as jalan. Alur dapat merupakan tempat menggenangnya air hujan yang jatuh di atas permukaan jalan, mengurangi tingkat kenyamanan, dan akhirnya dapat timbul retak-retak. Terjadinya alur disebabkan oleh lapis perkerasan yang kurang padat, dengan demikian terjadi tambahan pemadatan akibat repetisi beban lalu lintas pada lintasan roda. Campuran aspal dengan stabilitas rendah dapat pula menimbulkan deformasi plastis. Perbaikan dapat dilakukan dengan memberi lapisan tambahan dari lapis permukaan yang sesuai.

2. Keriting (Corrugation), alur yang terjadi melintang jalan. Penyebab kerusakan ini adalah rendahnya stabilitas campuran yang berasal dari terlalu tingginya kadar aspal, terlalu banyak mempergunakan agregat halus, agregat berbentuk bulat dan permukaan penetrasi yang tinggi. Keriting dapat juga terjadi jika lalu lintas dibuka 
sebelum perkerasan mantap (untuk perkerasan yang mempergunakan aspal cair). Kerusakan dapat diperbaiki dengan :

- Jika lapis permukaan yang keriting itu mempunyai lapis pondasi agregat, perbaikan yang tepat adalah dengan menggaruk kembali, dicampur dengan lapis pondasi, dipadatkan kembali dan diberi lapis permukaan baru.

- Jika lapis permukaan bahan pengikat mempunyai ketebalan $>5 \mathrm{~cm}$, maka lapis tipis yang mengalami keriting tersebut diangkat dan diberi lapis permukaan yang baru.

3. Sungkur (Shoving), deformasi plastis yang terjadi setempat, ditempat kendaraan sering berhenti, kelandaian curam dan tikungan tajam. Kerusakan dapat terjadi dengan/tanpa retak. Penyebab kerusakan sama dengan kerusakan keriting. Perbaikan dapat dilakukan dengan cara dibongkar dan dilapis kembali.

4. Amblas (Grade Depressions), terjadi setempat, dengan atau tanpa retak. Amblas dapat terdeteksi dengan adanya air yang tergenang. Air tergenang ini dapat meresap ke dalam lapisan perkerasan yang akhirnya menimbulkan lubang.

Penyebab amblas adalah beban kendaraan yang melebihi apa yang direncanakan, pelaksanaan yang kurang baik, atau penurunan bagian perkerasan dikarenakan tanah dasar mengalami settlement.

Perbaikan dapat dilakukan dengan :

- Untuk amblas yang $\leq 5 \mathrm{~cm}$, bagian yang rendah diisi dengan bahan sesuai seperti lapen, lataston, laston.

- Untuk amblas yang $\geq 5 \mathrm{~cm}$, bagian yang amblas dibongkar dan lapis kembali dengan lapis yang sesuai.

5. Jembul (Upheaval), terjadi setempat, dengan atau tanpa retak. Hal ini terjadi akibat adanya pengembangan tanah dasar pada tanah dasar ekspansif. Perbaikan dilakukan dengan membongkar bagian yang rusak dan melapisinya kembali.

c. Cacat Permukaan (Sisintegration) yang mengarah kepada kerusakan secara kimiawi dan mekanis dari lapisan perkerasan.

Yang termasuk dalam cacat permukaan ini adalah :

1. Lubang (Potholes), berupa mangkuk, ukuran bervariasi dari kecil sampai besar. Lubang-lubang ini menampung dan meresapkan air ke dalam lapis permukaan yang menyebabkan semakin parahnya kerusakan jalan.

Lubang dapat terjadi akibat:

a. Campuran material lapis permukaan jelek, seperti :

- Kadar aspal rendah, sehingga film aspal tipis dan mudah lepas.

- Agregat kotor sehingga ikatan antara aspal dan agregat tidak baik.

- Temperatur campuran tidak memenuhi persyaratan.

b. Lapis permukaan tipis sehingga ikatan aspal dan agregat mudah lepas akibat pengaruh cuaca.

c. Sistem drainase jelek, sehingga air banyak yang meresap dan mengumpul dalam lapis perkerasan.

d. Retak-retak yang terjadi tidak segera ditangani sehingga air meresap dan mengakibatkan terjadinya lubang-lubang kecil.

Lubang-lubang tersebut diperbaiki dengan cara dibongkar dan dilapis kembali. Perbaikan yang bersifat permanen disebut juga deep patch (tambalan dalam), yang dilakukan sebagai berikut :

a. Bersihkan lubang dari air dan material-material yang lepas.

b. Bongkar bagian lapis permukaan dan pondasi sedalam-dalamnya sehingga mencapai lapisan yang kokoh (potong dalam bentuk yang persegi panjang).

c. Beri lapis tack coat sebagai lapis pengikat.

d. Isikan campuran aspal dengan hati-hati sehingga tidak terjadi segregasi.

e. Padatkan lapis campuran dan bentuk permukaan sesuai dengan lingkungannya. 
2. Pelepasan butir (Ravelling), dapat terjadi secara meluas dan mempunyai efek serta disebabkan oleh hal yang sama dengan lubang. Dapat diperbaiki dengan memberikan lapisan tambahan di atas lapisan yang mengalami pelepasan butir setelah lapisan tersebut dibersihkan dan dikeringkan.

3. Pengelupasan lapisan permukaan (Stripping), dapat disebabkan oleh kurangnya ikatan antara lapis permukaan dan lapis di bawahnya, atau terlalu tipisnya lapis permukaan. Dapat diperbaiki dengan cara digaruk, diratakan dan dipadatkan. Setelah itu dilapisi dengan buras.

d. Pengausan (Polished Aggregate)

Permukaan jalan menjadi licin, sehingga membahayakan kendaraan. Pengausan terjadi karena agregat berasal dari material yang tidak tahan aus terhadap roda kendaraan, atau agregat yang dipergunakan berbentuk bulat dan licin, tidak berbentuk cubical. Dapat diatasi dengan menutup lapisan dengan latasir, buras atau latasbun.

e. Kegemukan (Bleeding or flushing)

Permukaan menjadi licin. Pada temperatur tinggi, aspal menjadi lunak dan akan terjadi jejak roda. Kegemukan (bleeding) dapat disebabkan pemakaian kadar aspal yang tinggi pada campuran aspal, pemakaian terlalu banyak aspal pada pekerjaan prime coat atau tack coat. Dapat diatasi dengan menaburkan agregat panas dan kemudian dipadatkan atau lapis aspal diangkat dan kemudian diberi lapisan penutup.

f. Penurunan Pada Bekas Penanaman Utilitas (Utility cut depression)

Terjadi di sepanjang bekas penanaman utilitas. Hal ini terjadi karena pemadatan yang tidak memenuhi syarat. Dapat diperbaiki dengan dibongkar kembali dan diganti dengan lapis yang sesuai.

\section{METODOLOGI PENELITIAN}

a. Pengumpulan Data

1. Data Primer

Data primer adalah suatu data yang didapat dengan melakukan pengamatan dan peninjauan secara langsung di lapangan. Survey yang dilakukan merupakan survey kondisi permukaan jalan. Survey dilakukan pada ruas jalan Kedungmundu-Metesih, meliputi :

- Jenis kerusakan jalan Jenis-jenis kerusakan yang ada direkap untuk setiap segmen jalan yang ditinjau. Semua jenis kerusakan dinilai secara visual kemudian setiap kerusakan ditandai dengan memberi batas dengan kedalamannya dengan menggunakan meteran.

- Tingkat kerusakan yang terjadi.

Kerusakan dinilai berdasarkan kualitas kerusakan apakah termasuk berat, sedang atau ringan dan juga kuantitasnya yang bisa dinyatakan dalam persentase kerusakan, perbandingan luas permukaan rusak dengan luas permukaan jalan yang ditinjau.

- Jumlah kerusakan.

Tiap jenis kerusakan jalan direkap dan dijumlahkan untuk setiap segmen yang ditinjau.

2. Data Sekunder

Data sekunder adalah merupakan suatu data yang didapat melalui instansiinstansi terkait, peta lokasi dan gambar teknis jalan Kedungmundu-metesih dari Dinas Pekerjaan Umum Propinsi Jawa Tengah.

b. Peralatan penelitian

Pada Penelitian ini menggunakan alat-alat berupa: kamera, buku catatan, pena, mistar, roll meter dan data-data penunjang lainnya yang didapat dari dinas dinas instansi terkait serta sumber data lain yang didapatkan dari berbagai sumber. 


\section{HASIL PENELITIAN}

Berdasarkan hasil survey yang dilakukan pada permukaan jalan Kedungmundu-Meteseh, didapat jenis-jenis kerusakan yang terjadi, yaitu bleeding, retak rambut, retak kulit buaya, alur, keriting, kerusakan tepi dan lubang-lubang. Berikut ini adalah hasil pengukuran persentase jenis-jenis kerusakan permukaan jalan Kedungmundu-Meteseh.

Tabel 1. Persentase Perbandingan Jenis-Jenis Kerusakan Yang Terjadi

\begin{tabular}{|c|l|c|c|}
\hline No & \multicolumn{1}{|c|}{ Jenis Kerusakan } & Luas $\left(\mathbf{m}^{\mathbf{3}} \mathbf{)}\right.$ & \% Kerusakan \\
\hline 1 & Bleeding & 482 & 39,18 \\
\hline 2 & Retak rambut dan retak kulit buaya & 456 & 37,07 \\
\hline 3 & Alur & 31 & 2,52 \\
\hline 4 & Keriting & 19 & 1,54 \\
\hline 5 & Kerusakan tepi & 210 & 17,07 \\
\hline 6 & Lubang-lubang & 32 & 2,60 \\
\hline 7 & Jembul Jumlah & 0,23 & 0,02 \\
\hline \multicolumn{2}{r|}{} & $\mathbf{1 2 3 0 , 2 3}$ & $\mathbf{1 0 0}$ \\
\hline
\end{tabular}

Sumber : Hasil Olahan Data

Jenis kerusakan yang terjadi pada ruas jalan tersebut sebagian besar berupa bleeding, retak rambut dan retak kulit buaya. Bleeding yang terjadi sebesar $482 \mathrm{~m}^{2}$ atau 39,18\% dari total kerusakan yang terjadi sepanjang Ruas Jalan tersebut. Hal ini dapat disebabkan pemakaian kadar aspal yang tinggi pada campuran aspal, pemakaian terlalu banyak aspal pada pekerjaan prime coat atau tack coat sehingga permukaan menjadi licin. Pada temperatur tinggi, aspal menjadi lunak dan akan terjadi jejak roda.

Sedangkan kerusakan retak rambut dan retak kulit buaya yang terjadi sebesar $456 \mathrm{~m}^{2}$ atau $37,07 \%$ dari total kerusakan yang terjadi sepanjang Ruas Jalan tersebut. Retak rambut ini dapat meresapkan air kedalam lapis permukaan. Retak rambut dapat berkembang menjadi retak kulit buaya. Retak kulit buaya dapat diresapi pula oleh air sehingga jika tidak segera ditangani dapat mengakibatkan terjadinya lubang-lubang kecil akibat terlepasnya butir-butir. Hal ini akan mengakibatkan sangat tidak nyamannya pengendara menggunakan jalan tersebut.

\section{KESIMPULAN DAN SARAN}

\subsection{Kesimpulan}

Setelah dilakukan penelitian pada ruas jalan Kedungmundu-Meteseh dapat ditarik kesimpulan sebagai berikut :

a. Berdasarkan survei kondisi jalan jenis kerusakan yang terjadi pada ruas Jalan Kedungmundu-Meteseh adalah bleeding, retak rambut, retak kulit buaya, alur, keriting, kerusakan tepi dan lubang-lubang.

b. Kemungkinan faktor-faktor penyebab kerusakan secara umum antara lain sistem drainase yang tidak baik, sifat material konstruksi perkerasan yang kurang baik, iklim, kondisi tanah yang tidak stabil, perencanaan lapis perkerasan yang tipis, proses pelaksanaan pekerjaan konstruksi perkerasan yang kurang sesuai dengan ketentuan yang tercantum dalam spesifikasi, yang saling terkait dan mempengaruhi.

c. Kerusakan jalan juga diakibat dari penanganan kerusakan (pemeliharaan jalan) tidak dilakukan secara dini dan tepat (kerusakan lubang yang terjadi akibat dari kerusakankerusakan kecil yang terus menerus dibiarkan, misalkan kerusakan retak yang telah menjadi lubang). 


\subsection{Saran}

a. Perlunya observasi langsung di lapangan oleh pihak terkait, agar perbaikan yang dilakukan sesuai dengan kondisi kerusakan yang terjadi, sehingga perbaikan yang dilakukan akan lebih efektif dan efisiensi.

b. Untuk mempertahankan kinerja perkerasan, diperlukan beberapa tindakan perbaikan kerusakan, baik berupa pemeliharaan rutin yang dilakukan setiap tahun maupun pemeliharaan berkala yang biasanya dilakukan 2 atau 3 tahun sekali.

\section{DAFTAR PUSTAKA}

AASHTO (1994) Apolicy on geometric Design of Higghways and Streets, American Assosiation of State Highway and transportation officials, Washington, DC.

Departemen Pekerjaan Umum Direktorat Jenderal Bina Marga Direktorat Bina Teknik, (Jilid I Metodae Survey).

Hardiyatmo, Hary Christady., 2007, Pemeliharaan Jalan Raya. Gadjah Mada University Press. Yogyakarta.

Information Note, Skid Resistance (Mu-meter) dan Laser Beam Profilometer (LBP).

John Watson B.Sc., M.I.C.E., 1989, Highway Construction and Maintenance, Second Edition, Longman Scientific \& Technical.

Manual Series No. 17 (MS-17). Asphalt Overlays for Highway and Street Rehabilitation, Asphalt Institute.

Shahin, M.Y, 1996, Pavement for Airports, Roads, Parking Lots, Chapman and Hall, Dept. BC., New York.

Sukirman, S., 1995, Perkerasan Lentur Jalan Raya, Penerbit NOVA, Bandung.

Sulaksono, S., 2001, Rekayasa Jalan, ITB, Bandung. 